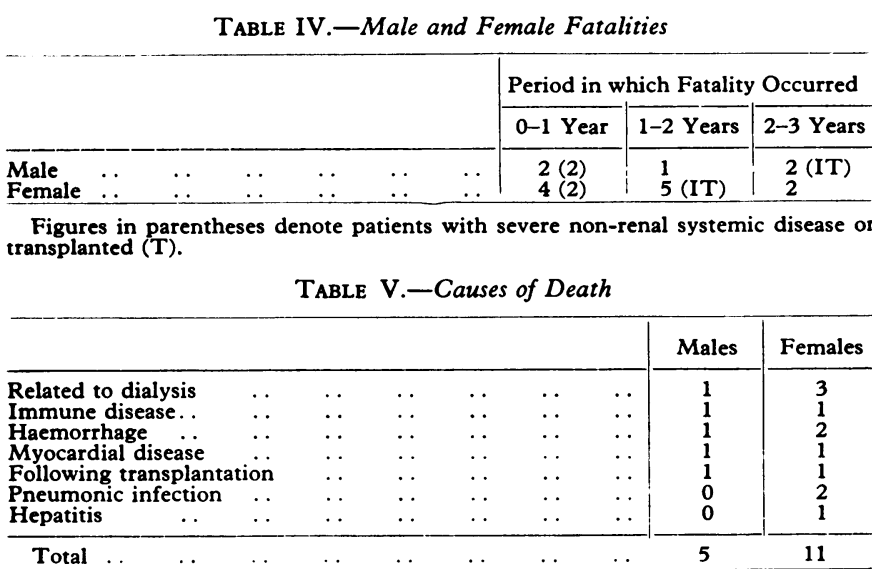

the standard errors applicable to each survival interval can be readily calculated. The calculation of survival rates, however, depends to a great extent on the number of patients considered, and the error of the predicted rate becomes unacceptable if the numbers are small.

Clearly, a high survival rate is attainable in the treatment of renal failure by home dialysis. Most of the patients in the series have been treated by this method. The fact that transplantation has apparently not adversely affected the survival rate, despite the failure of several transplants, is due to dialysis therapy being restarted after transplant failure.

In computing survival when both dialysis and transplantation have been used in the same patient dialysis periods have been assumed to be continuous. This is because the response to treatment of a patient who rejects a transplant and is returned to dialysis is comparable with that obtained before transplantation, with the possible exception of patients who have serious side effects from treatment with steroids and immunosuppressive agents. No more than one change of treatment occurred in the transplant patients considered here. Apparently survival is unrelated to social status, since both surviving and deceased patients came from all walks of life.
No systematic reason for the improved survival of men over women was found, but possibly women are less well able to tolerate the stress of the treatment. Firm conclusions cannot be drawn at this point, however, since the number of deaths is small. No difference between the survival rates of men and women was found by Lewis et al. (1970).

Though it is difficult to isolate factors contributing to survival, the role of medical, nursing, dietary, and organizational policies is clear. Technically superior performance in dialysis, dietary therapy, and the control of hypertension are of great importance. Similarly, it is essential that the patient assumes responsibility for dialysis and that direct links with advisers in the hospital are provided should a technical or medical problem arise. The patient definitely seems to appreciate and respond to efforts to restore him to his home and natural environment, particularly if this is done sympathetically but objectively.

The five-year overall survival rate of $80.7 \%$ for combined therapy in this programme is an improvement on the fiveyear survival rate of $57.8 \%$ reported by Lewis et al. (1969) for hospital dialysis alone, and probably home dialysis, with a four-year survival rate of $86.2 \%$, is mainly responsible for that improvement. This survival rate is certainly higher than that anticipated by existing plans for the treatment of renal failure, since it implies that very few of the dialysis population would die. Furthermore the results of a recent survey of the need for dialysis in Northern Ireland (M. McGeown, personal communication) show that 33 patients per million per year between the ages of 10 and 55 require regular dialysis therapy. This requirement is not met by the present programme.

\section{REFERENCES}

Baillod, R. A., Knight, A. H., Crockett, R. E, and Naish, P. F. (1969) In Dialysis and Renal Transplantation. Proceedings of the 6th Conference of the European Dialysis and Transplant Association, ed. D. N. S. Kerr,

p. 65. London, Pitman Medical.
Cutler, S. J., and Ederer, F. (1958). Fournal of Chronic Diseases, 8, 699.

Lewis, E. J., Foster, D. M., de la Puente, J., and Scurlock, C. (1969) Annals of Internal Medicine, 70, 311 .

Moorhead, J. F., Baillod, R. A., and Hopewell, J. P. (1970). Proceedings of the 4th International Congress of Nephrology. In press.

\title{
Malabsorption of Dietary Folate (Pteroylpolyglutamates) in Adult Coeliac Disease and Dermatitis Herpetiformis
}

\author{
A. V. HOFFBRAND, ${ }^{*}$ B.M., M.R.C.P., D.C.P. ; A. P. DOUGLAS, † M.B., M.R.C.P. \\ L. FRY, $\ddagger$ M.D., M.R.C.P. ; J. S. STEWART, $§$ M.B., M.R.C.P.
}

British Medical fournal, 1970, 4, 85-89

Summary : Tests of absorption of folic acid (pteroyl$\checkmark$ glutamic acid) and of dietary folates (pteroylpolyglutamates) were performed in 10 patients with untreated adult coeliac disease, five with dermatitis herpetiformis, and three with nutritional folate deficiency. Absorption of pteroylglutamic acid was impaired in eight patients with coeliac disease and in two with dermatitis herpetiformis. Absorption of pteroylpolyglutamates was impaired in all 10 coeliac patients and in four of the five patients with dermatitis herpetiformis. Absorption of both forms of folate was normal in all three patients with nutritional folate deficiency.

\footnotetext{
* Lecturer, Department of Haematology, Royal Postgraduate Medical School, London W.12.

t Research Fellow, Department of Gastroenterology and M.R.C Malabsorption Group, Royal Postgraduate Medical School, London W.12.

¥ Consultant Dermatologist, St. Mary's Hospital, London W.2. Consultant Physician, West Middlesex Hospital, Isleworth,
Middlesex.
}

Jejunal pteroylpolyglutamate hydrolase ("folate
conjugase"), the enzyme thought to be involved in
hydrolysis of dietary pteroylpolyglutamates during their
absorption, was normal in all patients tested, including 17
with adult coeliac disease, four with dermatitis herpe-
tiformis, and three with nutritional folate deficiency.
assayed microbiologically has been shown to occur in this disease by the demonstration of subnormal folate excretion (Girdwood, 1953) and subnormal rise in serum pteroylglutamic acid (Chanarin et al., 1958; Klipstein, 1966) after oral 
doses of pteroylglutamic acid. Subnormal absorption of tritiated pteroylglutamic acid has aiso been shown by both urinary and faecal excretion techniques to occur in adult coeliac disease (Anderson et al., 1960; Kinnear et al., 1963; Kremenchuzky et al., 1967; Stewart et al., 1967).

In a few patients with untreated aduit coeliac disease, however, the results of tests of pteroylglutamic acid absorption are normal even though severe folate deficiency is present (Chanarin et al., 1958; Anderson et al., 1960; Stewart et al., 1967). Moreover, occasional adult coeliac patients with megaloblastic anaemia show an excellent haematological response to pteroylglutamic acid when this is given by mouth in physiological (50-200 $\mu \mathrm{g}$.) doses, an ubservation which also suggests that absorption of pteroylglutamic acid is not grossly impaired in these particular patients (Mollin and Waters, 1968).

One possible explanation for this severe folate deficiency in the presence of normal absorption of pteroylglutamic acid is that in these patients absorption of food folate is more severely impaired than absorption of crystalline pteroylglutamic acid itself. Food folate consists largely of polyglutamate forms of folate in which the pteroyl portion of the molecule is linked to six, seven, or more glutamate moieties instead of to one glutamate moiety as in pteroylglutamic acid. These polyglutamate compounds are hydrolysed to pteroylmonoglutamate during absorption (Butterworth et al., 1969), probably by the enzyme pteroylpolyglutamate hydrolase (formerly called "folate conjugase") within the jejunal mucosa.

The main purpose of the present study was to compare the absorption of pteroylpolyglutamates and pteroylglutamic acid in patients with untreated adult coeliac disease and to measure the pteroylpolyglutamate hydrolase content of the jejunal mucosa in these patients. Since some patients with dermatitis herpetiformis show jejunal mucosal abnormalities similar to those found in coeliac disease, and such patients may also show folate deficiency despite normal absorption of pteroylglutamic acid (Fry et al., 1967), folate absorption tests and enzyme estimations were also performed in a group of folate-deficient patients with this skin disease.

Finally, the studies were performed in three patients diagnosed clinically as suffering from nutritional folate deficiency to exclude a defect in absorption of dietary folate as a factor in their deficiency state.

\section{Patients Studied}

Folate absorption tests were performed in the following patients :

(1) Ten Patients with Untreated Adult Coeliac Disease.-In each the diagnosis had been made on the demonstration of steatorrhoea and malabsorption of xylose, the grossly abnormal jejunal biopsy appearance, and the presence of folate deficiency (Table I). At the time of the present folate absorption studies these patients had received no treatment other than saturating doses of folic acid (see later). Jejunal pteroylpolyglutamate hydrolase activity was measured in eight of these patients and in a further seven with the untreated disease. The enzyme activity was also measured in two adult coeliac patients who were in remission while taking a gluten-free diet. These two patients had normal serum folate levels at the time a jejunal biopsy was taken for enzyme assay.

(2) Five Patients with Dermatitis Herpetiformis.-Each of these patients had skin lesions typical of this disease, for which they were receiving dapsone therapy. In addition each patient had folate deficiency (Table I). The jejunal biopsy of four showed a flat mucosa and "subtotal villous atrophy," and in one broad leafy villi were seen under the dissecting microscope, the histological appearances showing blunting of the villi and a pronounced cellular infiltrate.

(3) Three Patients with Nutritional Megaloblastic Anaemia.-In each of these cases the diagnosis was made because the patient developed megaloblastic anaemia which responded to a physiolo- gical dose of folic acid given by mouth and showed no evidence of malabsorption or of any other disease. Each patient was taking a grossly inadequate diet. In two patients jejunal biopsy was performed and each showed a normal mucosal pattern.

(4) Fourteen Healthy Normal Adult Volunteers.

feiunal Pteroylpolyglutamate Hydrolase Estimations.These were performed in 17 patients with adult coeliac disease, four with dermatitis herpetiformis, three with nutritional folate deficiency, and in 24 control subjects who had a variety of gastrointestinal symptoms but in whom no evidence of folate deficiency was present. Tests for absorption were all normal, no evidence of gastric or intestinal disease was found, and the jejunal mucosa appeared histologically normal.

\section{Methods}

Folate Absorption Tests.-Folate-deficient patients were first saturated with three successive daily intramuscular injections of $15 \mathrm{mg}$. of pteroylglutamic acid. The last injection was given 10 days before the first day of the absorption studies. Normal subjects were given a single oral dose of $5 \mathrm{mg}$. of folic acid 10 to 14 days before the test. The patient was then fasted overnight, a venous blood sample was withdrawn, and $0.45 \mu$ mole $(200 \mu \mathrm{g}$.) of pteroylglutamic acid was fed orally in $50 \mathrm{ml}$. of water. Venous blood samples were taken one, two, and three hours later. On one of the next two days the test was repeated except that $0.45 \mu$ mole of pteroylpolyglutamates (prepared from yeast) was fed instead of pteroylglutamic acid. Further details of the technique, including the method of preparation of pteroylpolyglutamates, have been previously described (Hoffbrand et al., 1969). The folate content of each blood sample was estimated microbiologically with Lactobacillus casei as test organism. In normal subjects the serum folate level ranges from 6 to $21 \mathrm{ng} . / \mathrm{ml}$. and levels below $3 \mathrm{ng} . / \mathrm{ml}$. are definitely abnormal (Waters and Mollin, 1961).

Estimation of Fejunal Mucosal Pteroylpolyglutamate Hydrolase ("Folate Conjugase").-Jejunal biopsy samples were obtained from the first part of the jejunum by use of a Crosby intestinal biopsy capsule (Crosby and Kugler, 1957), under radiological control. The pteroylpolyglutamate hydrolase activity was measured by incubating $0.1 \mathrm{ml}$. of homogenized biopsy material with $0.1 \mathrm{ml}$. of a specially prepared pteroylpolyglutamate substrate in $1.8 \mathrm{ml}$. of phosphate-citrate buffer at $\mathrm{pH}$ 4.6. The substrate itself was not microbiologically (L. casei) active. Pteroyltri-, di-, and monoglutamates released from the substrate by the enzyme are $L$. casei-active. The amount of $L$. casei-active folate released was measured and the activity of the enzyme was expressed as L. casei-active ("free") folate released per mg. of protein of mucosa in 90 minutes at $37^{\circ} \mathrm{C}$. Details of this enzyme assay are described elsewhere (Hoffbrand et al., 1969; Hoffbrand and Peters, 1969).

Other Methods.-Haematological methods were standard (Dacie and Lewis, 1968). Serum vitamin $\mathrm{B}_{12}$ levels were determined by microbiological assay with the "z" strain of Euglena gracilis (Anderson, 1964). Normal levels range from 160 to $925 \mathrm{pg} . / \mathrm{ml}$. Red cell folate levels are measured by microbiological assay with L. casei after haemolysis of whole blood. The levels in normal subjects range from 160 to $640 \mathrm{ng} . / \mathrm{ml}$. packed red cells (Hoffbrand et al., 1966).

\section{Results}

The relevant clinical and laboratory findings in the 10 adult coeliac patients, five patients with dermatitis herpetiformis, and three patients with nutritional folate deficiency in whom folate absorption tests were performed are shown in Table I. 
TABLE I.-Principal haematological findings and the jejunal biopsy appearances in the 18 patients in whom folate absorption tests were carried our

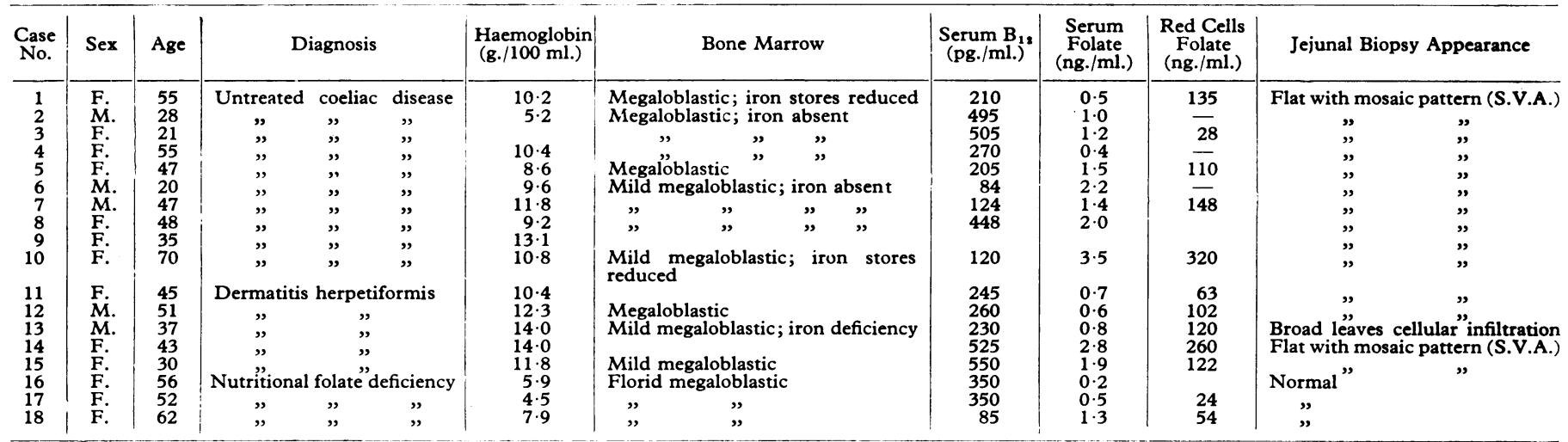

\section{Folate Absorption Tests}

Normal Subjects.- The absolute rise in serum folate in the 14 normal subjects following the oral dose of pteroylglutamic acid ranged from 7.5 to $22.0 \mathrm{ng} . / \mathrm{ml}$., with a mean of $11.5 \mathrm{ng} . / \mathrm{ml}$. (Table II). The absolute rise in serum folate following an equivalent oral dose of pteroylpolyglutamates ranged from 7.0 to $18.0 \mathrm{ng} . / \mathrm{ml}$, with a mean of $10.3 \mathrm{ng} . / \mathrm{ml}$. There was no significant difference in the overall rise in serum folate following the two different forms of folate ( $t$ test for paired samples, $\mathrm{P}=0 \cdot 1$ ).

Patients with Untreated Adult Coeliac Disease.-All but two of these 10 patients showed subnormal rises in serum folate following the oral dose of pteroylglutamic acid $(<7.5 \mathrm{ng} . / \mathrm{ml}$.), and in the remaining two (Cases 9 and 10 , Table III) the rises were just normal $(8.0$ and $9.8 \mathrm{ng} . / \mathrm{ml}$. respectively). An absorptive defect for pteroylpolyglutamates was even more frequent among these patients, since all 10 showed subnormal rises in serum folate $(<7.0 \mathrm{ng} . / \mathrm{ml}$.) following the oral dose of pteroylpolyglutamates. There was no statistically significant difference in the rise in serum folate following ingestion of the two forms of folate among these patients, however ( $t$ test for paired samples, $P=0.24$ ), though two patients (Cases 9 and 10) showed subnormal rises in serum folate after pteroylpolyglutamate ingestion and normal rises after pteroylglutamic acid.

Patients with Dermatitis Herpetiformis.-Only two of these five patients showed subnormal rises in serum folate after oral pteroylglutamic acid, whereas four of them showed subnormal rises after oral pteroylpolyglutamates (Table III). The overall rise following pteroylpolyglutamates was significantly lower than that following pteroylglutamic acid ( $t$ test for paired samples, $P=0.05$ ). One patient showed normal rises in serum folate after both forms of folate (Case 15, Table III).

TABLE II.-Peak rise in serum folate following oral doses of $0.45 \mu$ mole (200 $\mu \mathrm{g}$.) pteroylglutamic acid and $0.45 \mu$ mole pteroylpolyglutamates in 14 normal subjects

\begin{tabular}{|c|c|c|c|c|c|c|}
\hline \multirow{3}{*}{$\begin{array}{l}\text { Subject } \\
\text { No. }\end{array}$} & \multicolumn{6}{|c|}{ Serum Folate (ng./ml.) } \\
\hline & \multirow{2}{*}{$\begin{array}{c}\text { Fasting } \\
\text { Level }\end{array}$} & \multicolumn{2}{|c|}{$\begin{array}{l}\text { After } 0.45 \mu \mathrm{mole} \\
\text { Folic Acid }\end{array}$} & \multirow[b]{2}{*}{$\begin{array}{l}\text { Fasting } \\
\text { Level }\end{array}$} & \multicolumn{2}{|c|}{$\begin{array}{c}\text { After } 0.45 \mu \text { mole } \\
\text { Pteroylpolyglutamate }\end{array}$} \\
\hline & & $\begin{array}{l}\text { Peak } \\
\text { Rise }\end{array}$ & $\begin{array}{l}\text { Time } \\
\text { (Hours) }\end{array}$ & & $\begin{array}{l}\text { Peak } \\
\text { Rise }\end{array}$ & $\begin{array}{c}\text { Time } \\
\text { (Hours) }\end{array}$ \\
\hline $\begin{array}{r}1 \\
2 \\
3 \\
4 \\
5 \\
6 \\
7 \\
8 \\
9 \\
10 \\
11 \\
12 \\
13 \\
14\end{array}$ & $\begin{array}{r}13.0 \\
15.5 \\
14.0 \\
13.2 \\
6.3 \\
10.0 \\
13.5 \\
7.2 \\
4.7 \\
14.5 \\
5.5 \\
15.0 \\
4.6 \\
7.1 \\
\end{array}$ & $\begin{array}{r}10.5 \\
22.0 \\
8.7 \\
9.6 \\
13.6 \\
10.7 \\
11.5 \\
7.5 \\
10.3 \\
14.0 \\
9.3 \\
9.0 \\
12.6 \\
12.0 \\
\end{array}$ & $\begin{array}{l}2 \\
2 \\
2 \\
1 \\
1 \\
2 \\
3 \\
2 \\
2 \\
1 \\
2 \\
2 \\
2 \\
1\end{array}$ & $\begin{array}{r}10.0 \\
10.0 \\
18.5 \\
15.0 \\
8.4 \\
7.6 \\
16.0 \\
13.5 \\
15.8 \\
12.4 \\
5.6 \\
14.0 \\
5.3 \\
7.1\end{array}$ & $\begin{array}{r}12.0 \\
18.0 \\
9.5 \\
8.5 \\
12.5 \\
7.4 \\
11.7 \\
9.9 \\
11.6 \\
9.4 \\
9.5 \\
9.0 \\
8 \cdot 1 \\
7.0\end{array}$ & $\begin{array}{l}2 \\
2 \\
2 \\
2 \\
3 \\
2 \\
2 \\
2 \\
1 \\
1 \\
3 \\
2 \\
3 \\
2\end{array}$ \\
\hline Mean. & $10 \cdot 3$ & 11.5 & & $11 \cdot 4$ & $10 \cdot 3$ & \\
\hline
\end{tabular}

TABLE III.-Peak rise in serum folate following oral doses of $0.45 \mu$ mole pteroylglutamic acid and 0.45 umole pteroylpolyglutamates in the patients with untreated adult coeliac disease, dermatitis herpetiformis, and nutrtitional folate deficinecy. Fejunal pteroylpolyglutamate hydrolase levels are given in the right-hand column

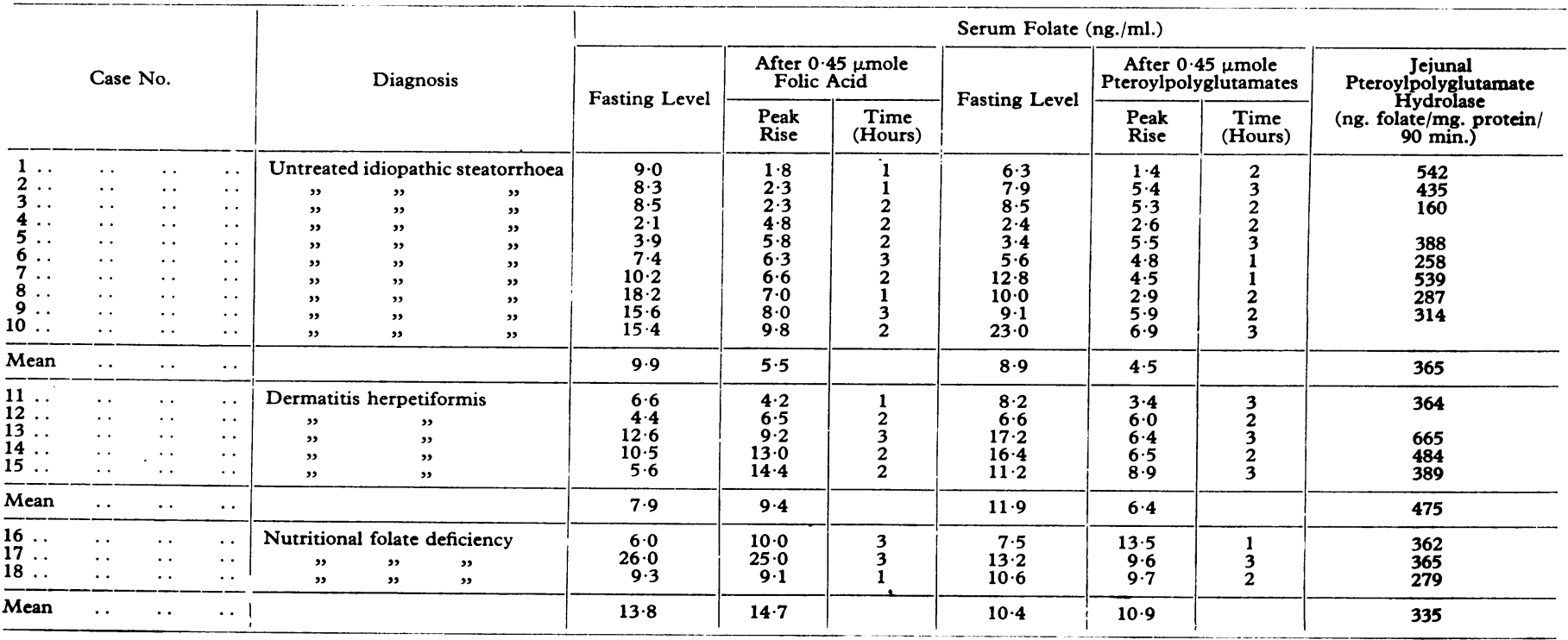


Patients with Nutritional Folate Deficiency.-All three patients showed normal rises in serum folate after ingestions of both pteroylglutamic acid and pteroylpolyglutamates (Table III).

\section{Jejunal Pteroylpolyglutamate hydrolase levels}

There was no significant difference between the concentration of pteroylpolyglutamate hydrolase in the jejunal mucosa in any of the conditions studied (see Chart). In 24 control subjects the levels ranged from 120 to 893 with a mean of $369 \mathrm{ng}$. folate released $/ \mathrm{mg}$. protein $/ \mathrm{S0}$ minutes. The mean level (378 $\mathrm{ng}$. folate $/ \mathrm{mg}$. protein $/ 90$ minutes) and range (from 140 to $882 \mathrm{ng}$. folate/mg. protein/90 minutes) among the 17 adult coeliac patients were not significantly different from that of the normal subjects, nor was there any difference between the levels of the enzyme in untreated coeliac patients and those taking a gluten-free diet. The enzyme levels were also normal in the four patients with dermatitis herpetiformis

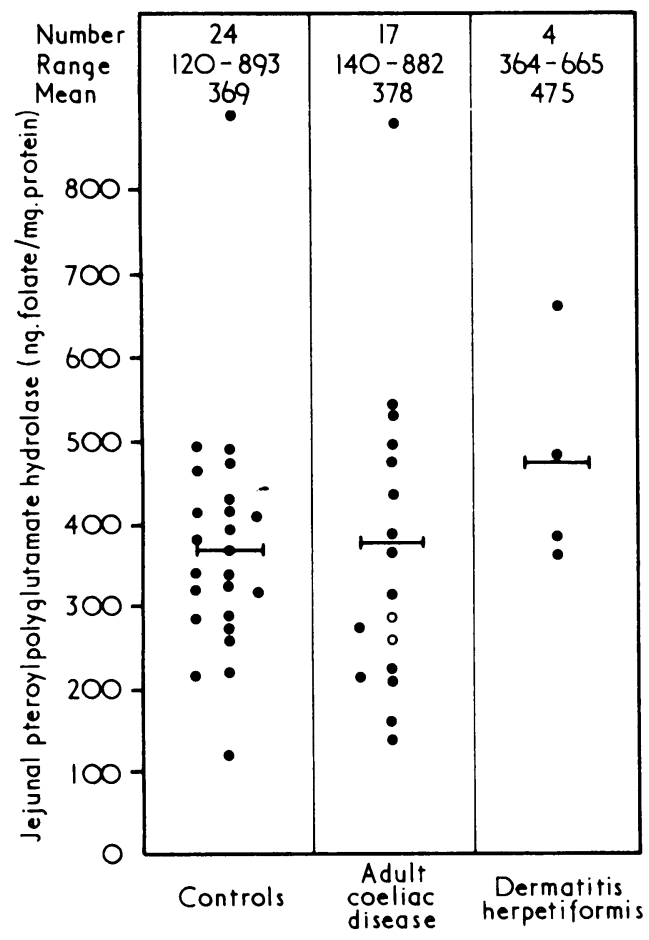

Jejunal pteroylpolyglutamate hydrolase concentrations in 24 control subjects, 15 patients with untreated coeliac disease (closed circles), two patients with coeliac disease receiving a gluten-free diet (open circles), and four patients with dermatitis herpetiformis.

tested (range from 364 to 665 ; mean $475 \mathrm{ng}$. folate/mg. protein/90 minutes) and in three patients with nutritional folate deficiency (range from 279 to 365 ; mean $335 \mathrm{ng}$. folate $/ \mathrm{mg}$. protein/90 minutes).

\section{Discussion}

These results confirm those of many previous workers that malabsorption of pteroylglutamic acid occurs in patients with coeliac disease. They also show that most adult patients with coeliac disease have an equally severe defect in absorption of pteroylpolyglutamates, the major form of dietary folate. In patients with untreated tropical sprue absorption of pteroylpolyglutamates is usually more severely impaired than absorption of pteroylglutamic acid (Jeejeebhoy et al., 1968; Hoffbrand et al., 1969), and, as mentioned earlier, it seemed possible that in occasional adult coeliac patients a similar dissociation between the absorptive capacities for the two forms of folate might be present. Two of the 10 coeliac patients tested here did show malabsorption of pteroylpolyglutamates, despite having normal absorption of pteroylglutamic acid, but there was no overall significant difference in the degree of malabsorption of the two forms of folate, and, in general, the patients with the most severe malabsorption of pteroylpolyglutamates also showed the most severely impaired absorption of pteroylglutamic acid.

Some patients with dermatitis herpetiformis closely resemble coeliac patients by showing a similar jejunal lesion which responds to gluten withdrawal. Folate deficiency in this disease has not been satisfactorily explained, however, since absorption of pteroylglutamic acid was normal in all but one of the 12 patients tested (Fry et al., 1967) even though in many of these patients the jejunal mucosa was abnormal and folate deficiency present. Our study shows that absorption of pteroylpolyglutamates was impaired in four out of five patients with dermatitis herpetiformis, and suggests that folate deficiency in this disease is at least partly due to malabsorption of dietary folate.

The defect of absorption of dietary pteroylpolyglutamates in the coeliac syndrome may be partly due to loss of jejunal mucosal absorptive surface and partly to damage to the surface cells. The reduction of effective pore size of the jejunal mucosal cells in coeliac disease may also interfere with absorption of both pteroylpolyglutamates and pteroylmonoglutamates, including pteroylglutamic acid (Fordtran et al., 1967). Possibly also there is a defect of some enzyme concerned with folate absorption and this causes malabsorption of folate. One enzyme thought to be necessary for absorption of the polyglutamate forms of folate is pteroylpolyglutamate hydrolase. This enzyme is localized to the lysosomes of the jejunal mucosal cells (Hoffbrand and Peters, 1969), and on histological and histochemical evidence these subcellular organelles are damaged in coeliac disease (Riecken et al., 1966). No defect of this enzyme was detected here, however, in jejunal biopsy samples.

Nordio et al. (1970) found raised levels of $\beta$-glucuronidase in the jejunal mucosa in untreated coeliac disease. This is a lysosomal enzyme, and hence probably there is no general deficiency of lysosomal enzymes in this disease. It is unlikely, therefore. that a defect in hydrolysis of pteroylpolyglutamates due to lack of pteroylpolyglutamate hydrolase in the mucosa is a limiting factor in absorption of dietary folate in coeliac disease, though we cannot exclude the possibility that there may be a defect in activity of the enzyme in vivo not reflected by a reduction of the in-vitro activity. For instance, enzyme levels are expressed here in terms of protein concentration in the biopsy specimen. Since the volume of epithelial cells is subnormal and the number of inflammatory cells is increased in a given volume of mucosa in untreated coeliac disease, it is conceivable that the total amount of enzyme in the mucosal. absorptive cells is reduced in this disease.

Other enzymes may well be concerned in absorption of folates. Infants have been reported by Luhby et al. (1961) and Lanzkowsky et al., (1969) with a specific defect of absorption of preroylglutamic acid. This suggests that absorption of pteroylglutamic acid itself requires enzymatic processes. Chanarin and Perry (1969) showed that partly reduced forms of folate-for example, dihydrofolic acid-are further reduced to the tetrahydrofolate derivative and then methylated during absorption. Possibly the jejunal mucosa in coeliac disease lacks one of the enzymes concerned in these reactions. Baker et al. (1968) also postulated that non-enzymatic processes are concerned in the absorption of pteroylglutamic acid, since they found that feeding calf jejunum considerably improved absorption of pteroylglutamic acid in coeliac disease and tropical sorue and that this effect of calf jeiunum was still present after the material had been autoclaved.

Folate deficiency in these malabsorption syndromes may not be simply due to reduced absorption of dietary monoglutamate and polyglutamate forms of folate. Exfoliation of jejunal mucosal cells is now known to be increased several 
times normal in coeliac disease (Croft et al., 1968). The jejunal mucosal cells contain small but significant amounts of folate mainly in the polyglutamate form (Hoffbrand and Peters, 1969). Failure of reabsorption of this folate as well as of that contained in bile (S. J. Baker et al., 1965) could well contribute to the development of folate deficiency in both coeliac disease and dermatitis herpetiformis.

Most workers consider that dietary folate deficiency occurs frequently in Western communities. This is consistent with the generally accepted concept of Herbert (1968), that minimal daily requirements for folate $(100 \mu \mathrm{g}$.) are not many times lower than normal daily dietary folate intake (500 to $1,000 \mu \mathrm{g}$.). A few workers, however, suggest that daily folate requirements are as little as $10 \mu \mathrm{g}$. (see Vitale, 1966). If this were so it would be extremely difficult to develop the deficiency simply by taking a poor diet. It would therefore be necessary to postulate that some degree of malabsorption of dietary folate occurred in many patients diagnosed clinically as suffering from "pure" nutritional folate deficiency. The present results, however, show normal absorption of pteroylpolyglutamates and normal jejunal mucosal pteroylpolyglutamate hydrolase levels in three such patients and thus support the concept of inadequate dietary intake of the vitamin as the sole cause of their deficiency.

We are grateful to Professor C. C. Booth for helpful encouragement and advice during this investigation and for permission to study patients under his care. We also wish to thank Dr. P. D. Roberts and Dr. A. Knudsen for the laboratory investigations of the patients studied at the West Middlesex Hospital, Dr. Nigel Evans for several of the intestinal biopsies, and Mr. J. Morgan, Mrs. C. Griffin, and Miss A. Quinlan for expert technical help.

\section{REFERENCES}

Anderson, B. B. (1964). fournal of Clinical Pathology, 17, 14. Anderson, B., Belcher, E. H., Chanarin, I., and Mollin, D. L. (1960) British fournal of Haematology, 6, 439.
Baker, H., Frank, O., Ziffer, H., Feingold, S., and Cintron Rivera, A. A. (1968). British Medical fournal, 3, 472.

Baker, S. J., Kumar, S., and Swaminathan, S. P. (1965), Lancet, 1, 685

Butterworth, C. E., Baugh, C. M., and Krumdieck, C. (1969). Fournal of Clinical Investigation, 48, 1131 .

Chanarin, I., Anderson, B. B., and Mollin, D. L. (1958). British fournal of Haematology, 4, 156.

Chanarin, I, and Perry, J., (1969). Lancet, 2, 776.

Croft, D. N., Loehry, C. A., and Creamer, B. (1968). Lancet, 2,

Crosby, W. H., and Kugler, H. W. (1957). American fournal of Digestive Diseases, 2, 236.

Dacie, J. V., and Lewis, S. M. (1968) Practical Haematology, 4th ed. London, Churchill.

Fordtran, J. S., Rector, F. C., Lochlear, T. W., and Ewton, M. F. (1967) Fournal of Clinical Investigation, 46, 287

Fry, L., Keir, P., McMinn, R. M. H., Cowan, J. D., and Hoffbrand,

Girdwood, R. H. (1953). Lancet, 2, 53.

Herbert, V. (1968). American fournal of Clinical Nutrition, 21, 743.

Hoffbrand, A. V., Necheles, T. F., Maldonado, N., Horta, E., and Santini, R. (1969). British Medical fournal, 2, 543.

Hoffbrand, A. V., Newcombe, B. F. A., and Mollin, D. L. (1966) fournal of Clinical Pathology, 19, 17.

Hoffbrand, A. V., and Peters, T. J. (1969). Biochimica et Biophysica Acta, 192, 479.

Jeejeebhoy, K. N., Desai, H. G., Borkar, A. V., Deshpande, V., and Pathare, S. M. (1968). American fournal of Clinical Nutrition, 21, 994.

Kinnear, D. G., Johns, D. G., MacIntosh, P. C., Burgen, A. S. V., and Cameron, D. G. (1963). Canadian Medical Association fournal, 89, 975.

Klipstein, F. A. (1966). Bulletin of the New York Academy of Medicine, 42.638.

Kremenchuzky, S., Musso, A. M., Hoffbrand, A. V., and Viola, E. M. R. (1967). Fournal of Nuclear Biology and Medicine, 11, 89. Lanzkowsky, P., Erlandson, M. E., and Bezan, A. I. (1969). Blood, 34, 452.

Luhby, A. L., Eagle, F. J., Roth, E., and Cooperman, J. M. (1961). American Fournal of Diseases of Childhood, 102, 482

Mollin, D. L., and Waters, A. H. (1968). In Occurrence, Causes, and Prevention of Nutritional Anaemias. Symposia of the Swedish Nutrition Foundation, ed. G. Blix, vol. 6, p. 121. Uppsala, Almquist and Wiksells.

Nordio, S., et al. (1970). Helvetica Paediatrica Acta, 25, 62.

Riecken, E. O., Stewart, J. S., Booth, C. C., and Pearse, A. G. E. (1966). Gut, 7, 317.

Stewart, J. S., Pollock, D. J., Hoffbrand, A. V., Mollin, D. L., and Booth, C.'C. (1967). Quarterly fournal of Medicine, 36, 425.

Vitale, J. J. (1966). Nutrition Reviews, 24, 289. Waters, A. H., and Mollin, D. L. (1961). Fournal of Clinical Pathology,
14, 335.

\footnotetext{
* Senior Registrar, the General Hospital, Birmingham 4.

$\dagger$ Medical Registrar, the General Hospital, Birmingham 4.

$\ddagger$ Consultant Physician, the General Hospital, Birmingham 4 .
}

of all cases were the result of respiratory infections. Respiratory disease may be responsible for the larger number of patients with ketoacidosis seen in the winter months (FitzGerald et al., 1961). Some infections may disturb diabetic control more than others, and this paper reports an "epidemic" of diabetic ketoacidosis which occurred during the recent influenza outbreak.

\section{Methods}

Twenty-nine patients were admitted to hospital as medical emergencies, either sent by general practitioners or brought in by anxious relatives. Of these patients, 23 already attended the diabetic clinic at the General Hospital, Birmingham, where about 5,000 patients are currently treated. The remaining six were found to be diabetics on admission.

Blood glucose was measured by the AutoAnalyzer ferricyanide method, blood acetoacetate by the AutoAnalyzer method of Salway (1969), serum potassium by the AutoAnalyzer, and blood $\mathrm{pH}, \mathrm{PCO}_{2}$, and standard bicarbonate by the Astrup microelectrode. Patients are described as "nonketotic" when the ketonaemia was insufficient to cause alteration of the blood acid-base status: this is usually the case when the blood acetoacetate is less than $1.5 \mathrm{mM}$. 